International Journal of Current Advanced Research

ISSN: O: 2319-6475, ISSN: P: 2319 - 6505, Impact Factor: SJIF: 5.995

Available Online at www.journalijcar.org

Volume 6; Issue 3; March 2017; Page No. 2384-2388

DOI: http://dx.doi.org/10.24327/ijcar.2017.2388.0014

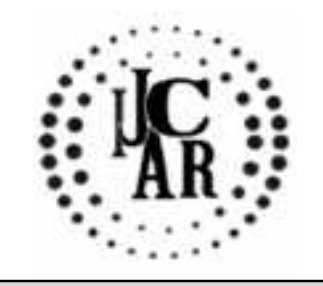

Research Article

\title{
CYTOMORPHOLOGICAL SPECTRUM OF PAPANICOLAOU SMEARS - A HOSPITAL BASED RETROSPECTIVE STUDY
}

\section{Anjana Sharma*1., Somendra Kumar Dhariwal² and Pritam Khairkar³}

1,2Assistant Professor, Department of Pathology, Shri Shankaracharya Institute of Medical Sciences, Bhilai, Chhattisgarh

3Professor and Head, Department of Pathology, Shri Shankaracharya Institute of Medical Sciences, Bhilai, Chhattisgarh

\begin{tabular}{|c|c|}
\hline A R T I C L E I N F O & A B S T R A C T \\
\hline $\begin{array}{l}\text { Article History: } \\
\text { Received } 19^{\text {th }} \text { December, } 2016 \\
\text { Received in revised form } 24^{\text {th }} \text { January, } 2017 \\
\text { Accepted } 12^{\text {th }} \text { February, } 2017 \\
\text { Published online } 28^{\text {th }} \text { March, } 2017\end{array}$ & $\begin{array}{l}\text { Cervical cancer is second most common cancer of women in India. Screening of cervical } \\
\text { cytology by simple papinocolou smear is an effective tool to detect premalignant lesions of } \\
\text { cervix. Present study was retrospectively done to determine the cytomorphological } \\
\text { spectrum of various cervical lesions and categorize them according to Bethesda system. All } \\
\text { the patients presenting in gynaecological OPD and health camps with gynaecological } \\
\text { complaints were included and subjected for PAP smear. Most common complaint and } \\
\text { physical examination finding was abnormal vaginal discharge }(46.3 \%) \text { and erosion on } \\
\text { cervix }(46 \%) \text { respectively. A total of } 300 \text { cervical smears were evaluated out of which } 22 \\
(7.3 \%) \text { cases were unsatisfactory for evaluation, } 49(16.3 \%) \text { were Negative for } \\
\text { intraepithelial lesion or malignancy (NILM) and 196(65.3\%) of NILM inflammatory } \\
\text { category. Epithelial cell abnormality were seen in } 33(11 \%) \text { with ASCUS in } 15 \text { (5\%), LSIL } \\
\text { in } 12(4 \%) \text { and HSIL in } 6(2 \%) \text { cases. Maximum number of abnormal cases } 15 \text { (5.3\%) were } \\
\text { in age range } 40-49 \text {. Cases of carcinoma were not encountered. The study enforces the } \\
\text { significance of PAP smear screening in all the women at appropriate interval for reducing } \\
\text { prevelance of cervical cancer in developing country like India. }\end{array}$ \\
\hline
\end{tabular}

Copyright $\bigcirc 2017$ Anjana Sharma et al. This is an open access article distributed under the Creative Commons Attribution License, which permits unrestricted use, distribution, and reproduction in any medium, provided the original work is properly cited.

\section{INTRODUCTION}

Cancer cervix is a disease of global burden and stands as third most common cancer in women worldwide (Sreedevi A et al 2015). In India it is second most common cancer with a peak incidence 55-59 years (Dhananjaya S et al 2014) Mortality varies eighteen fold between the different regions of the world, with rates ranging from less than 2 per 100,000 in Western Asia, Western Europe and Australia/New Zealand to more than 20 per 100,000 in Melanesia, Middle and Eastern Africa as per GLOBACON cancer fact sheet. According to world health organization approximately $80 \%$ of cervical cancer deaths occurred in developing countries. In India the mortality rate varies between $9.8-17.5$ per 100,00 . Without urgent intervention, deaths due to cervical cancer are projected to rise by almost $25 \%$ over the next 10 years. (Consul S et al 2012)

The high mortality rates is attributable to the presentation of patient at later stages of disease. It is partly contributed because of subtle clinical features of disease.

*Corresponding author: Anjana Sharma

Assistant Professor, Department of Pathology, Shri

Shankaracharya Institute of Medical Sciences, Bhilai,

Chhattisgarh
Most of the disease comes into attention only after the onset of symptoms and unfortunately in late stages. One of the major management challenges encountered is late presentation, as more than $56.0 \%$ of the cases present in stages III and IV. (Eze JN et al 2013). Data suggest that more than half of cervical cancer cases could be prevented through adequate screening. Fifty percent of women diagnosed with cervical cancer have never undergone cervical cytology testing and another $10 \%$ have not received screening in the five years preceding their diagnosis. Furthermore, cervical cancer is very rare among screened women as less than 10 per 100,000 annual (Sokol RJ et al2003). This outlines the significance of regular and periodic screening of all sexually active women. The cancer in spite of being highly prevalent is easily preventable by routine screening of cervical cytology by simple Papanicolaou smear.

The incidence of squamous cell carcinoma of cervix has been reduced significantly since the introduction of PAP smear .It has been proved to be a highly effective tool for detecting CIN and early cervical cancer so that the condition can be managed or treated to prevent disease progression. (Vesco KK et al 2011). The sensitivity of the test can be increased by cotesting with HPV DNA (Bamanikar SA et al 2014) However, the recommendation on age group and frequency of testing varies among different countries. According to the The 
American Cancer Society Guidelines for the Prevention and Early Detection of Cervical Cancer the screening should start at age of 21 years.

Among various preventive strategies annual Pap smear screening programme is still most cost-effective with additional HPV DNA testing being a cost-effective choice under a reasonable threshold of willingness to pay. (Chen MK et al 2011). It has been well established that well-organized screening by cytology has substantially reduced the incidence of morbidity and mortality from cervical cancer in developed countries (Hakama M 1986). Strategies that aim to ensure that all the women are screened at appropriate interval and receive adequate follow up are most likely to be successful in further reducing cervical cancer. Therefore the present study is undertaken to determine the cytomorphological spectrum of various cervical lesions.

\section{MATERIAL AND METHODS}

This study was conducted on 300 pap smears at Shri Shankaracharya Institute of Medical sciences, Bhilai, Chhattisgarh, India after clearance from the local ethical committee .The study included all patients attending gynecology OPD and heath camps with complaints of vaginal discharge, post coital bleeding, inter-menstrual bleeding, dyspareunia, pain in lower abdomen and other gynaecological complaints.

Collection- Pap smear was performed by opening the vaginal canal with a speculum and collecting cells from the outer opening of the cervix at the transformation zone with Ayre's spatula. The cellular material thus obtained was quickly, but gently smeared on a clean glass slide .Two smears were prepared for each case. Then the smear was immersed and fixed in $95 \%$ ethanol. This part of the collection was done by the gynaecologists and the glass slides were sent to department of pathology. The glass slide was then stained according to papanicolaou's technique (RAPID PAP ${ }^{\text {TM }}$ Kit) and the slides were examined under light microscope and were reported by two pathologists. The cytological interpretation of the smears was done according to the new 2001 Bethesda system Analysis- The statistical methodology in this study was done by simple statistical calculation using Microsoft Excel sheet calculation.

\section{RESULTS}

A total number of 300 PAP smear were examined. Out of 300 cases majority were in age group 30-39 years followed by 40-49 years. Females more than 60 years contributed only $1.7 \%$. Majority of the females were in the age group 30-50 years. $(69 \%)$. [TABLE 1$]$.

Table 1 Distribution of cases according to age $(n=300)$

\begin{tabular}{ccc}
\hline $\begin{array}{c}\text { Age } \\
\text { group(years) }\end{array}$ & $\begin{array}{c}\text { Number of } \\
\text { Cases }\end{array}$ & $\begin{array}{c}\text { Percentage } \\
\text { \% }\end{array}$ \\
\hline $20-29$ & 62 & 20.7 \\
$30-39$ & 104 & 34.7 \\
$40-49$ & 103 & 34.4 \\
$50-59$ & 26 & 8.7 \\
60 or more & 5 & 1.7 \\
Total & $\mathbf{3 0 0}$ & $\mathbf{1 0 0}$ \\
\hline
\end{tabular}

Out of all 300 smears screened, $22(7.3 \%)$ of the cases were unsatisfactory for evaluation. A total of 278 smears were found to be satisfactory for evaluation. Evaluation of these
278 smears revealed $49(16.3 \%)$ cases Negative for intraepithelial lesion or malignancy (NILM ) having normal cytological findings and 196 were NILM inflammatory category $(65.3 \%)$ showing inflammatory cells along with benign epithelial cell showing nonspecific reactive changes associated with inflammation (Figure 1). A total of 5 cases $(1.6 \%)$ were atrophic in NILM (Figure 2), 17 cases of bacterial infection and 2 cases of candida in NILM inflammatory category. On the other hand 33 smears $(11 \%)$ were found to be abnormal having epithelial cell abnormality.

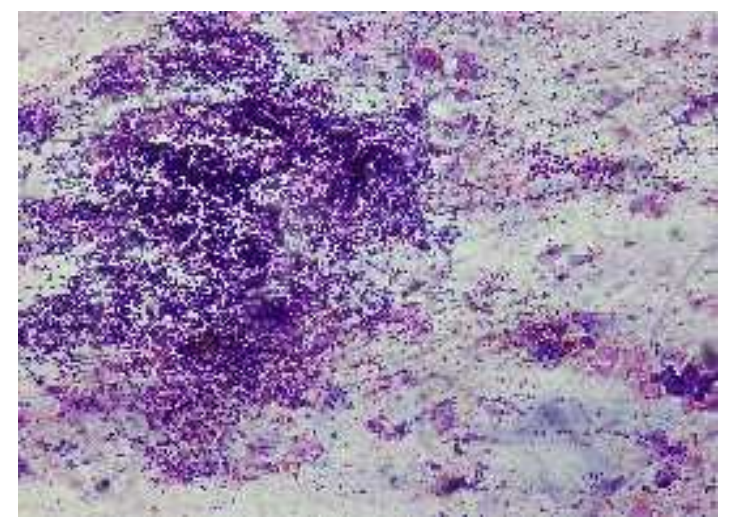

Figure 1 NILM (Negative for Intaepithelial lesion or malignancy) with inflammation

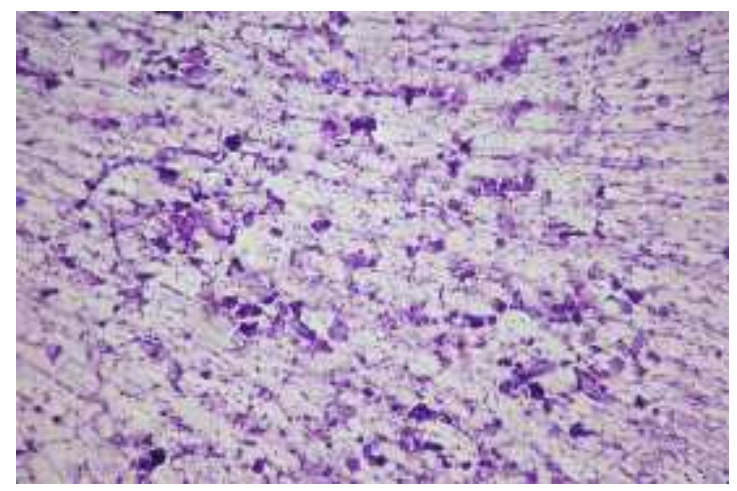

Figure 2 NILM (Negative for intraepithelial lesion or malignancy) Atrophic smears

The abnormal smears were further categorized as ASCUS (atypical Squamous cell of unknown significance), LSIL (low grade squamous intraepithelial lesion) and HSIL (high grade squamous intraepithelial lesion) [TABLE 2]

Table 2 Distribution of Cases according to type of Lesion $(n=300)$

\begin{tabular}{cccc}
\hline Sr.No. & Diagnosis & $\begin{array}{c}\text { Number of } \\
\text { Cases }\end{array}$ & Percentage (\%) \\
\hline 1 & Unsatisfactory for evaluation & 22 & 7.3 \\
& Negative for intraepithelial & & 16.3 \\
2 & lesion Normal/ Nos & 44 & \\
& Atrophic & 5 & \\
& Negative for intraepithelial & & 65.3 \\
3 & lesion Inflammatory & 177 & \\
& Bacterial & 17 & 5 \\
4 & Candida & 2 & 4 \\
5 & ASCUS & 15 & 2 \\
6 & LSIL & 12 & 0 \\
7 & HSIL & 6 & 0 \\
8 & Squamous cell carcinoma & 0 & 0 \\
9 & AGCUS & 0 & 0 \\
10 & Adenocarcinoma & 0 & $\mathbf{1 0 0}$ \\
\hline
\end{tabular}


Maximum number of abnormal cases $15(5 \%)$ were in age range $40-49$ years followed by 8 cases $(2.6 \%)$ in age group $30-$ 39 years. LSIL and HSIL were most common in age group 40-49 years. Cases of carcinoma including squamous cell carcinoma and adenocarcinoma were not encountered .Out of all abnormal smears majority was ASCUS 15 (5\%) followed by LSIL $12(4 \%)$ (Figure 3) and HSIL 6(2\%).[Table 3]

The most common complaint was abnormal vaginal discharge $(46.3 \%)$ in 140 females followed by pain abdomen $(15.3 \%)$ and intermenustral and irregular bleeding in (10.3\%) cases. Among the physical examination findings erosion on cervix (46\%) was most common finding followed by bulky cervix $(10.6 \%)$ on per speculum examination.(Table 4$)$

\section{DISCUSSION}

A total of 300 pap smear was collected between January 2016 and February 2017. Out of them a total of $22(7.3 \%)$ of smears were found to be unsatisfactory. The percentage of inadequate smear varies widely between different studies 0.2 to $13.94 \%$. (Misra JS et al 2006, Gupta K et al 2013).The results of present study is comparable with Bamanikar et al 2014 (5.7\%) and Bhhattacharya et al 2016 (8.3\%). Appropriate method of collection of smears by gynaecologists in our institute accounted for the higher number of adequate smears. (Table 5)

Table 3 Age - wise distribution of Lesion

\begin{tabular}{|c|c|c|c|c|c|c|c|c|}
\hline $\begin{array}{l}\text { Age group } \\
\text { (Years) }\end{array}$ & $\begin{array}{l}\text { Number } \\
\text { of cases }\end{array}$ & ASCUS & LSIL & HSIL & $\begin{array}{c}\text { Squamous } \\
\text { cell } \\
\text { carcinoma }\end{array}$ & $\begin{array}{c}\text { AGCUS/ } \\
\text { Adenocarcinoma }\end{array}$ & $\begin{array}{c}\text { Total No. of } \\
\text { Abnormal } \\
\text { finding }\end{array}$ & Percentage $\%$ \\
\hline $20-29$ & 62 & 3 & 0 & 0 & 0 & 0 & 3 & 1 \\
\hline $30-39$ & 104 & 5 & 3 & 0 & 0 & 0 & 8 & 2.6 \\
\hline $40-49$ & 103 & 4 & 6 & 5 & 0 & 0 & 15 & 5.0 \\
\hline $50-59$ & 26 & 3 & 3 & 0 & 0 & 0 & 6 & 2.0 \\
\hline 60 or more & 5 & 0 & 0 & 1 & 0 & 0 & 1 & 0.3 \\
\hline Total & 300 & 15 & 12 & 6 & 0 & 0 & 33 & $11 \%$ \\
\hline
\end{tabular}

Table 4 Clinical Presentations and distribution of Lesion

\begin{tabular}{|c|c|c|c|c|c|c|c|c|}
\hline Clinical Features & No.of Case & Percentage \% & $\begin{array}{c}\text { NILM } \\
\text { Inflammatory }\end{array}$ & ASCUS & LSIL & HSIL & $\begin{array}{c}\text { Squamous } \\
\text { cell } \\
\text { carcinoma }\end{array}$ & $\begin{array}{c}\text { AGCUS/ } \\
\text { Adenocarcinoma }\end{array}$ \\
\hline Vaginal Discharge & 140 & 46.3 & 94 & 7 & 1 & 2 & 0 & 0 \\
\hline Pain In Abdomen & 46 & 15.3 & 27 & 1 & 1 & 0 & 0 & 0 \\
\hline Post menopausal Bleeding & 13 & 4.3 & 04 & 1 & 1 & 1 & 0 & 0 \\
\hline Low back pain & 30 & 10 & 20 & 1 & 1 & 0 & 0 & 0 \\
\hline Burning Micturition & 1 & 0.3 & 01 & 0 & 1 & 0 & 0 & 0 \\
\hline Dysmenorrhea & 10 & 3.3 & 08 & 1 & 2 & 0 & 0 & 0 \\
\hline Post coital bleeding & 8 & 2.6 & 3 & 1 & 2 & 1 & 0 & 0 \\
\hline Prolapse & 20 & 6.6 & 15 & 1 & 2 & 1 & 0 & 0 \\
\hline Intermenustral bleeding & 32 & 10.6 & 24 & 2 & 1 & 1 & 0 & 0 \\
\hline Total & 300 & - & 196 & 15 & 12 & 6 & $\mathbf{0}$ & $\mathbf{0}$ \\
\hline
\end{tabular}

Table 5 Comparison of the findings of PAP smear in present study with other studies

\begin{tabular}{|c|c|c|c|c|c|c|c|c|}
\hline Name of author & $\begin{array}{c}\text { Number of } \\
\text { cases }\end{array}$ & $\begin{array}{l}\text { Inadequate } \\
\text { smear }(\%)\end{array}$ & $\begin{array}{c}\text { Normal } \\
(\%)\end{array}$ & $\begin{array}{c}\text { NILM } \\
\text { inflammatory }\end{array}$ & ASCUS & LSIL & HSIL & Malignancy \\
\hline $\begin{array}{c}\text { Bhhattacharya N Bet al } \\
(2016)\end{array}$ & 288 & 8.3 & 20 & 51.4 & 1.4 & 8.3 & 3.5 & 0.3 \\
\hline Nandwani et al(2016) & 5813 & 5.7 & 11.8 & 74.9 & 3.6 & 2.5 & 2.7 & 3.6 \\
\hline Vaghela et al(2014) & 400 & 13.2 & 4.5 & 53 & 2.8 & 15 & 6 & 3.0 \\
\hline BamanikarA S et al(2014) & 560 & 5.7 & 16.9 & 71.9 & 2.3 & 1.9 & 0.3 & 0.5 \\
\hline Manjit et al (2012) & 300 & 4 & 16.7 & 74.3 & 0.3 & 2.7 & 0.7 & 1.3 \\
\hline Sherwani et al (2007) & 160 & 69 & - & - & - & 10.6 & 0.6 & 3.7 \\
\hline Karuma et al (2003) & 100 & - & 31 & - & 6 & 7 & 5 & - \\
\hline Present study(2017) & 300 & 7.3 & 16.3 & 65.3 & 5 & 4 & 2 & - \\
\hline
\end{tabular}

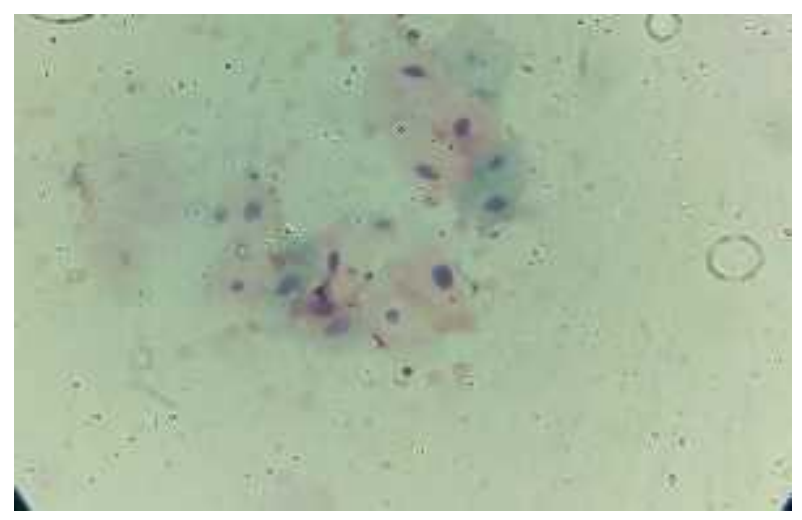

Figure 3 Epithelial cell abnormality - LSIL (Low grade squamous intraepithelial lesion)
The most common complaint recorded was abnormal vaginal discharge $46.3 \%$ and most common per speculum finding was cervical erosion $(46 \%)$. The PAP smear were done either as part of routine screening procedure or in females with complaints. This was in accordance with Sherwani R K et al (2007) and Khattak AT et al 1 (2006) in which discharge per vaginum was most common finding in $42.5 \%$ and $41 \%$ respectively. In the study by Pradhan et al (2007) per vaginal discharge was found to be commonest complaints in different lesion of cervix however bleeding PV is found to be more specific for cervical malignancy. Our study also correlates with the above fact and signifies that PAP smear should always be done in patient with vaginal discharge as it can be a warning symptom for intraepithelial lesions. 
The present study revealed $16.3 \%$ of smears as NILM with no abnormality which is close to $16.7 \%$ and $16.9 \%$ reported by Manjit Singh Bal et al (2012) and Bamanikar AS et al respectively. Some studies have reported a higher percent of NILM including Khattack ST et al (2006) as $61.6 \%$. The reason for lower percentage of normal smear as compared to abnormal can be because of increased referral of only symptomatic patients in our tertiary care hospital.

The nonspecific inflammation with no epithelial abnormality was seen in $65.3 \%$ cases as compared to Bhattacharya et al, (2016) Vaghela et al (2014) who reported lower rates. Khattak et al (2006) also reported lower percentage as $32 \%$. However studies by other authors have shown a slightly higher rate. [Table 3]. The difference in socioeconomic strata, living conditions and hygienic behaviour may account for the difference. The patient population of women from suburban and near by rural areas mostly from poor socioeconomic status accounted for percentage in present study.

The total of ECA (epithelial cell abnormality) reported in our study was $33(11 \%)$. The percentage of ECA vary widely in different corners of the world and between developed and developing countries with $0.98 \%$ in Jewish Israeli women (Banaik U et al 2011) to $15.5 \%$ in rural population of Zimbabwe (Thistle PJ 1997). The prevelance in US is 2.3$6.6 \%$ and in middle east $1.65-7.9 \%$. (Gupta $\mathrm{K}$ et al 2013). In India the prevelance is $1.3-26.8 \%$. (Vaghela et al 2014).

The less number ECA reported in our study may be due vigilant screening of the symptomatic patients in early phases by gynaecologists in our hospital.

The ECA was most prevalent in age group 40-49(50\%). Other studies have similar findings Banik U et al (2011) who reported EAC peak in more than 45 years and Vaghela et al (2014) with maximum ECA (26 \%) in 40-49 years. Another study from Nepal reported $80 \%$ of ECA more than 40 years. (Ranabhat S K 2011) The study enforces the regular and thorough screening by PAP smear in the women above 40 years of age The higher prevelance of ECA in studies from India and in our study suggests the lack of awareness about routine cervical screening in our women population and unfortunately they presents only when symptomatic and at later stages of disease.

The most frequent ECA in our study was ASCUS (45.4\%). Other studies also reported ASCUS as the most common epithelial cell abnormality. (Bamanikar et al 2014, Patel et al 2004, Ghaith J.E. et al 2012). The ASCUS to SIL ratio in our study was 1.5:1 which confers with the ratio recommended as the adequate screening marker. (Renshaw AA et al 2009). The results of LSIL and HSIL also varied among different studies. The results of present study are comparable to that of (Manjit et al 2012) and (Nandwani et al 2016.). However some have reported a higher prevalence (Karuna et al 2003) and some lower. [TABLE 5].No case of malignancy was reported in our case. The reason might be that gynaecologist in our institute prefer to send cervical biopsy over PAP smear in case of suspected malignant lesion.

\section{CONCLUSION}

In a developing country like India with limited resource and meagre heath care facilities conventional PAP smear still proves to be a boon for screening pre invasive lesions of cervix and preventing morbidity and mortality. This study recommends the vigilant and through screening of females especially after 40 years as the epithelial cell abnormality tend to occur more in this age group. Every women should be educated about importance of regular screening along with warning symptoms. They should be encouraged for timely gynaecological visit with Pap smear request.

\section{Reference}

Sreedevi A, Javed R, Dinesh A. Epidemiology of cervical cancer with special focus on India. International Journal of Women's Health. 2015; 7:405-414. doi:10.2147/IJWH.S50001.

Dhananjaya S, Aparna K. Current Status of Cancer Burden: Global and Indian scenario. Biomed Res J. 2014; $1(1): 1-5$

Consul S, Agrawal A, Sharma H, Bansal A, Gutch M, Jain N. Comparative study of effectiveness of Pap smear versus visual inspection with acetic acid and visual inspection with Lugol's iodine for mass screening of premalignant and malignant lesion of cervix. Indian $J$ Med Paediatr Oncol 2012; 33:161-5

Eze JN, Emeka-Irem EN, Edegbe FO. A Six-Year Study of the Clinical Presentation of Cervical Cancer and the Management Challenges Encountered at a State Teaching Hospital in Southeast Nigeria. Clinical Medicine Insights Oncology. 2013; 7:151-158.

Sokol RJ, Blackwell SC, American College of Obstetricians and Gynecologists. Committee on Practice Bulletins-Gynecology. ACOG practice bulletin: shoulder dystocia. Number 40, November 2002. (Replaces practice pattern number 7, October 1997). Int J Gynaecol Obstet. 2003 Jan; 80(1):87-92

Vesco KK, Whitlock EP, Eder M, et al.Rockville (MD): Screening for Cervical Cancer: A Systematic Evidence Review for the U.S. Preventive Services Task Force Agency for Healthcare Research and Quality (US); 2011 May.

Bamanikar SA, Baravkar DS, Chandanwale SS, dapkekar P. Study of Cervical Pap Smears in a Tertiary Hospital. Indian Medical Gazette. 2014:250-254.

Chen MK, Hung HF, Duffy S, Yen AM, Chen HH. Costeffectiveness analysis for Pap smear screening and human papillomavirus DNA testing and vaccination. $J$ Eval Clin Pract. 2011 Dec; 17(6):1050-8.

Hakama M, Miller AB, Day NE. Screening for cancer of the uterine cervix. In Screening for cancer of the uterine cervix 1986 (pp. 315-315).

Misra JS, Singh U. Results of long term hospital based cytological screening in asymptomatic women. Diagn Cytopathol. 2006; 34:184-7.

Gupta K, Malik NP, Sharma VK, Verma N, Gupta A. Prevalence of cervical dysplasia in western Uttar Pradesh. Journal of Cytology/Indian Academy of Cytologists. 2013 Oct; 30(4):257.

Bhattacharyya, Nandini Bhaduri, et al. "Cytological profile of Pap smears in a tertiary care hospital of West Bengal, India." International Journal of Reproduction, Contraception, Obstetrics and Gynecology 5.12 (2016): 4397-4400.

Sherwani R K, Khan T, Akhtar K, Zeba A, Siddiqui F A, Rahman K, Afsan N. Conventional Pap smear and 
liquid based cytology for cervical cancer screening - a comparative study. J Cytol 2007; 24:167-72

Khattak ST, Khattak I, Naheed T, Akhtar S, Jamal T. Detection of abnormal cervical cytology by pap smears. Gomal J Med Sci. 2006; 4:74-7.

Pradhan N, Giri K, Rana A. Cervical cytology study in unhealthy and healthy looking cervix. $N \mathrm{~J}$ Obstet Gynaecol. 2007; 2:42-7.

Manjit Singh Bal, Rishu Goyal, Anil Kumar Suri, Manjit Kaur Mohi . J Cytol. 2012 Jan-Mar; 29(1): 45-47.

Vaghela, Bhavika, Vikas K. Vaghela, and Pravina M. Santwani. "Profile of PAP smear cytology and its histopathological correlation at tertiary care center-A retrospective study." International Journal of Biomedical and Advance Research 5.1 (2014): 47-49.

Banik U, Bhattacharjee P, Ahamad SU, Rahman Z. Pattern of epithelial cell abnormality in Pap smear: A clinicopathological and demographic correlation. Cyto Journal. 2011; 8:8.

Thistle PJ, Chirenje ZM. Cervical cancer screening in a rural population of Zimbabwe. The Central African journal of medicine. $1997 \mathrm{Sep}$; 43(9):246-51.
Ranabhat, SK, Shrestha R, Tiwari M. Analysis of abnormal epithelial lesions in cervical Pap smears in MidWestern Nepal. Journal of Pathology of Nepal. 2011; $1: 30-3$.

Patel TS, Bhullar C, Bansal R, Patel S M. Interpreting epithelial cell abnormality detected during cervical smear screening - A cytohistologic approach. Eur $J G$ Oncol.2004; 25:725-8.

Ghaith J.E., Rizwana B.S. - Rate of Opportunistic Pap smear Screening and Patterns of Epithelial Cell Abnormalities in Pap Smears in Ajman, United Arab Emirates. Sultan Qaboos Univ Med J; 12 (4): 473478, 2012.

Renshaw AA, Deschênes M, Auger M. ASC/SIL Ratio for Cytotechnologists. American journal of clinical pathology. 2009 Jun 1; 31(6):776-81.

Nandwani RR, Totade S, Krishnan MG. Cytomorphological evaluation of squamous cell abnormalities observed on cervical smears in government medical college, Jabalpur, India: a five year study. International Journal of Research in Medical Sciences. 2016; 4(3):794-9.

Karuna, gaspanal v, Van Dan Brule R: The clinical profile and cervical cytomorphology, Indian journal of pathol.microbiol.46 (2) 782003.

\section{Please cite this article in press as:}

Anjana Sharma., Somendra Kumar Dhariwal and Pritam Khairkar (2017), Cytomorphological spectrum of papanicolaou smears - a hospital based retrospective study', International Journal of Current Advanced Research, 6(3), pp. 2384-2388. http://dx.doi.org/10.24327/ijcar.2017. 2388.0014 